\title{
Measuring Sustainable Performance among Logistic Service Providers in Supply Chains
}

\author{
Jerko ORŠIČ, Bojan ROSI, Borut JEREB
}

\begin{abstract}
To enable an objective measurement of the progress in the operation of third-party logistics service providers in supply chains, we developed a model that shows the sustainability of the outsourced elements of a company's business. The Third-Party Logistics Green Innovative Framework (3PL GIF) is based on selected environmental, economic, and social indicators showing the objectively comparable state and progress in sustainable development between different companies in goods distribution. The model incorporates the application of quality measurement standards and a PDCA cycle system of continuous improvement into indicators. Using this model, we surveyed the success of sustainable operations between different Slovenian logistics companies according to their size, fields of operation, and positions in the supply chain. The study found that the model provides comparisons of sustainable operation for supply chain operators, logistics companies, and the entire interested public. It also enables supply chain management companies to measure, improve, and report on its performance in a sustainable field, as well as to move toward goals determined by the company with its cycle of permanent improvement. This makes it possible to objectively compare progress in sustainable development between companies.
\end{abstract}

Keywords: distribution of goods; logistics service providers; performance measurement; supply chains; sustainability; third-party logistics; 3PL GIF index

\section{INTRODUCTION}

Sustainable development creates and maintains conditions in which people and nature exist in effective harmony to enable them to meet the social, economic and other requirements of present and future generations[1], leads to the accountability of environmental responsibility, reduction of the consumption of resources and responsibility towards the whole society. Process of implementing a sustainable operation requires monitoring of operation and reporting of performance, with constant efforts to improve the situation [2].

Logistic activities of transport and storage can involve many different suppliers in the supply chain business network in terms of size, equipment and ability to properly display their operation [3]. In addition, supply chains are changing rapidly [4], various companies and their subcontractors are integrated, on which we often do not have any information about their sustainable operation.

Despite this state of affairs, information on the sustainable efforts of the participating companies and the quality of the implementation of logistics processes are extremely important. All stakeholders in the distribution of goods are interested in how they have burdened the environment and caused other sustainable consequences [5], [6], [7]. In addition, interested public wants to know how to deal with employees, how safe is work in transport and storage; they are properly educated and paid, in order to choose better transport, more efficient storage and compare sustainable performance among different logistics companies.

Because of the various motives, we have listed so far, many companies report on the way they operate [8], but each in their own way by choosing a wide variety of criteria and data and a vague methodology in obtaining data [9].

Researchers follow a trend of increasing influence in the management of supply chains [10] described the measurement of the success of the supply chain at the levels of strategy, tactics and performance. As stated [11], sustainable development (on all three fields of sustainable: environment, economy and society) is getting increasingly important in logistics. This opens up a new Green Supply Chain Management (GSCM) sometimes declared as sustainable [12], which requires a different approach in strategy and decision-making based on knowledge and competences in a sustainable environmental field. Carter \& Rogers presents a proposal for a new SCM framework based on the theory of dependence on resources, transaction costs, population ecology and resources available in the company [13]. Srivastava describes GSCM as a strategy that integrates environmental thinking into the entire supply chain management (SCM) [14]. Sharma argues that permanent improvements are needed in the field of supply chain management due to increasing demands for success in all fields [15]

Customers of logistics services, especially in Europe and US, are increasingly oriented towards sustainability and require transport and storage providers to demonstrate their sustainability. Current practice is, as reported in [16], that contracts for the provision of logistic services, especially in large logistics, contain enormous questionnaires on sustainability requirements, and monitoring the implementation of these requirements is undetermined and as such problematic. In 3PL study in Italy, factors that encourage or inhibit the introduction of sustainable requirements for logistics companies were analyzed [17].

On the other hand, Marchet et al. showed in the analysis of 72 different scientific articles on environmentally sustainable logistics, that articles are not focused on sustainability initiatives and that there is a large shortage of research and publications in this field [18].

Among the various frameworks for measuring environmental performance we list some of the most important ones: [19] presents the PSR model (pressurestate-response) where, due to various human activities, pressure on the environment is created by the deterioration of the quality and quantity of natural resources, thus changing the state of the environment. To these changes, we need to respond with appropriate environmental protection measures.

In 1996 World Bank [20] has, with the statement "Sustainable is to leave future generations with at least as many opportunities as we had ourselves, if not more," added beside economic and environmental also social criteria to the PSR framework, thus establishing a 
triangular framework for the environmentally sustainable development of the ESD (Environmentally Sustainable Development). Generally recognized Triple Bottom Line was presented by Elkington [21] for economic performance, improvement and measurement of environmental performance, and care for social environment on the example of Shell UK.

According to ISO 14031 [22], a performance measurement system with continuous improvements has been created in the PDCA (Plan-Do-Check-Act) a fourphase recurring cyclic system of continuous improvement. Three types of PSR performance indicators are foreseen, namely environmental indicators (ECI), operational indicators (OPIs) and performance management indicators (MPI). Based on the ECI (Environmental Condition Indicator) measurement, we obtain data on the state of the environment due to our activities such as groundwater level decrease in meters, harmful concentrations of solid particles in air per $\mathrm{m}^{3}$. OPI (Operational Performance Indicator) indicators provide information at the operational level of the company, such as average fuel consumption per $100 \mathrm{~km}$, energy consumed per unit of product, water consumption per unit of product. MPI (Management Performance Indicator) measures the performance of management, such as the percentage of achieved environmental objectives in relation to the planned number of environmental incidents per year, an increase in the budget foreseen for environmental management. Zhu, Sarkis \& Lai described the example of a GSCM measurement model with five important groups in different fields of activity [23].

Walmart as one of the most important logistics company, an assessment of the sustainability of its suppliers was made based on a questionnaire in various fields. Thus, in the field of energy and climate, it assesses the reduction of energy costs, reduction of air emissions, efficient handling of materials, reduction of waste and enhancement of product quality, conservation of natural resources with the purpose of responsible obtained raw materials, achievement of high quality products and in the field of community assesses responsible and ethical production [24].

Nehm and Schwemmer proposed a two dimensional model for measuring the sustainable operation of logistics companies [25]. Concept dimension measures the strategy of sustainable policy, cooperation with science, releases of $\mathrm{CO}_{2}$, volume of resource consumption, certificates for the environmental performance of subcontractors. It measures dimension deals with the field of protection of natural resources, optimized transport, packaging method and the use of intralogistics, improvement of fleet management, real estate and implementation of measures in the social areas.

\section{METHODOLOGY}

Green innovative framework 3PL GIF presents a logical structure which describes and perceives the overall environmental behavior of logistics companies. We named the model after the most widespread and demanding case, when logistics services are provided by external contractors who only have a contractual relationship with the customer. Thus, the 3PL GIF is abbreviation for The
Third-Party Logistics Green Innovative Framework - for external contractors of logistics services.

It is based on three generally recognized sustainable fields, where we measure sustainable operation, namely environmental, social and economic. The 3PL GIF checks the implementation of business policy in all three fields and records progress in implementation. The 3PL GIF concept is designed to alert companies through indicators to use quality standards, by which they should carry out logistic activities, measure them, and constantly improve them cyclically. Indicators [26] that show performance in all three fields are grouped into a 3PL GIF index. The 3PL GIF model allows companies involved in logistic distribution processes to measure progress in their performance by PDCA principle.

Indicators have a direct or indirect basis in international standards in areas where they reflect the situation and include internationally recognized procedures for achieving these standards. Sharing the corporate responsibility is extremely important to achieve environmental performance, which is achieved with all participants using ISO 14000 [27] standard [28]. If the company does not use standard quality measurement systems, then this is a very important piece of information that indicates that the company does not have a relevant sustainable policy.

For each field of the environment, society and economy we have a selected group of indicators, which in the most general and simple way show the success of the sustainable operation of a logistics company. They are relevant, causally related, and are assessed comprehensively and easily. The method of obtaining data for the indicators must be constant, reliable and at a low cost as they should be [15],[17], [29],[30].

Normalization is based on the measurement of distance from the target [31], and on this principle, the indicators that we defined in our work are also based.

The importance of indicators is presented with weights, which means that the result of a particular indicator can be more valuable than the result of another indicator. In our case, we have set equal importance to all indicators so that we do not have different weights, as we emphasize that all three fields of environment, society and economy are equally important in sustainable development.

In addition, data for indicators in companies are already mostly prepared, as they are based on the acquired data which is required in implementing the standards.

3PL GIF index describes the sustainability of the company as a stakeholder in the supply. The index is a quantitative combination of indicators represented in Table 1, that can provide a simplified, coherent and multidimensional view of the system that presented a data pyramid showing how to get from data to finding about progress towards achieving sustainable development [32],[33]. The pyramid shows the entire information structure from data through indicators to a unified index, which in a concentrated form shows the situation in the whole field.

However, 3PL GIF index has the following features:

- It provides an easy comparison between companies and serves as a quick overview of how well they 
progress in achieving set goals in all three fields of sustainable operation.

- Improving logistics activities in the sustainable field. With the 3PL GIF index, we wanted for companies to focus on those fields they did not pay enough attention previously. At the same time, the 3PL GIF index shows the areas in which they are weak and proposes to increase activity in these areas to set new goals and try to improve their performance.

- Reliability of results due to the model's reliance on the use of standards, the verification of company performance data is included in the standard itself and is verified by independent evaluators.

- Easy retrieval of data for the 3PL GIF index. Companies that use standards have most of the data already collected because the 3PL GIF indicators include a lot of data that is collected due to the use of standards.

- Reporting on sustainable performance. Instead of a very long sustainability report, the publication of the 3PL GIF index can be easily reported to all stakeholders in a clear and comparable way.

\begin{tabular}{|c|c|c|}
\hline & Business policy & Performance measurement \\
\hline Environment & $\begin{array}{l}\text { Success of environmental standard use } \\
\text { Reduction of energy consumption } \\
\text { Reduction of the scope of recycling } \\
\text { Reduction of environmental incident }\end{array}$ & $\begin{array}{l}\text { Measuring and reporting on environmental performance } \\
\text { Reduction of emissions into the air } \\
\text { Reduction of water pollution and consumption } \\
\text { Reduction of solid waste }\end{array}$ \\
\hline Social & $\begin{array}{l}\text { Improvement of employee social security } \\
\text { Improvement of logistical production safety } \\
\text { Improvement of working conditions }\end{array}$ & $\begin{array}{l}\text { Improvement of work environment quality } \\
\text { Increase of preventive measures } \\
\text { Reduction of accidents } \\
\text { Increase of education }\end{array}$ \\
\hline Economy & $\begin{array}{l}\text { Market share increase } \\
\text { Income and profitability increase } \\
\text { Operation by code of conduct } \\
\text { Economic effort to ensure green production }\end{array}$ & $\begin{array}{l}\text { Cost reduction due to lean logistics } \\
\text { Cost reduction per Stock Keeping Unit(SKU) } \\
\text { Improvement of transportation economic efficiency } \\
\text { Reduction of energy, waste water, waste costs }\end{array}$ \\
\hline
\end{tabular}

\subsection{Indicators of Environment}

In Tab. 1 indicators in the field of environment were divided into two segments. In the first segment, the company evaluates its environmental policy, in the second one we show the consequences of the company's operations on the environment and measures to improve the situation.

Indicator of the success of environmental standards use indicates whether the company uses standards that ensure that the environmental policy is implemented. Indicator shows how committed is the company to planning, implementing and measuring in the environmental field according to performance standards such as ISO14000 or the corresponding second international standard in logistics activities [9]. By using standards, we know that it uses already integrated PDCA system, which enables constant progress and reporting on the environmental performance in logistics services.

Indicator of energy consumption reduction indicates how a committed company implements the environmental policy because reducing energy consumption per unit of product or service means the implementation of lean logistics as energy-efficient assets are used and reduces unnecessary activities.

Recycling indicator shows the company's concern for waste materials. This indicator shows how the company anticipates and implements the waste recycling policy and measures the extent of recycling in logistics activities.

Indicator of environmental incidents shows that the company is aware of the problems of ecological incidents that may arise due to various causes from the spill of dangerous substances to the careless attitude towards the transport or storage of dangerous goods, and the like. With this indicator we show that the company records the state of ecological incidents and wants to reduce it with the measures envisaged.
Indicator of measuring and reporting on environmental operations shows an active approach to continuous monitoring of its operation by measuring the environmental impact and reporting on its operation.

Indicator of reducing emissions of substances into the air in logistics activities shows what attention and how the company carries out its air pollution commitments since transport is one of the most polluting activities in air pollution. In addition to the legal requirements for measuring discharges, especially in transport, it shows how the company controls the environmental burden in its entire operation from waste management, inland transport, warehousing processes, operation of buildings and the use of renewable sources.

Indicator of the reduction of pollution and water consumption shows the company's attitude to the main source of life and a healthy environment since logistics besides the air also greatly burdens water resources.

Indicator of solid waste reduction emphasizes the importance of proper management of solid waste reduction in all logistical activities. This way, we can successfully reduce waste, especially when using appropriate, often applicable logistic packaging, using standard SKUs, optimizing the repacking of products and proper handling of bulk cargoes.

\subsection{Indicators of Society}

Indicators in the field of company's social performance (see Tab. 1) show how the company is managed by personnel who perform logistic services, because in transport and storage people are the key factor for the successful implementation of logistics processes. Indicators are divided into two groups, namely indicators that check the company's social policy and a set of indicators that indicate the implementation of activities to improve the social situation. 
Indicator of employee social security highlights the improvement of employees' social security, the sustainability of employment, increase in wages, benefits for employees, achieving or exceeding the ILO standards, thus showing the social security policy for their employees.

Indicator of logistical production safety points to improving security in logistics by implementing the company's security policy, which commands measurement and continuous improvement.

Indicator of working conditions improvement shows the concern of the company to ensure that employees are not under too much stress, have time to eat and rest, have a proper working time allocation, and the like.

Indicator of work environment quality improving is an indicator that shows how the company implements a policy of improving the working environment, so that employees have an ergonomically regulated work place, are not exposed to adverse effects, are responsible for setting up successful work teams and the like.

Indicator of the increase in preventive measures shows the company's actions due to the requirements of the security policy, to prevent in advance not only injuries but also stress and other burdens that negatively affect the welfare of workers.

Indicator of accidents reduction in the use of work tools reports how security policy is performing.

Indicator of education draws attention to the increase of education per employee, as the condition for successful work is education of employees by continuous education due to rapidly changing technology and the introduction of new information solutions.

\subsection{Indicators of Economy}

Indicators in the field of economic performance (see Table 1) of the company present the economic policy indicators of companies that show the overall economic performance of the company, as if the company operates successfully, it can provide the necessary means for more sustainable operation in the field of logistics. With these indicators we, in addition to financial performance of the company, also emphasized the importance of green and lean business and fair business behavior. The second group of economic indicators shows the measurement of savings due to green economic policy.

Indicator of market share shows how the company is successful in winning the logistics market. By expanding its business, the company displays market performance, healthy growth, and an increase in the scope of its operations.

Indicator of income and profitability is an important indicator of an increase in net revenue in the logistics segment, making it easier to finance a more sustainable company policy [34].

Indicator of code of conduct shows company's credibility and commitment to fair business practices in business transactions. We summarize it after the highly influential Dow Jones sustainability index, where bribery and other inappropriate methods represent an important economic risk as stated by Koepfel [35]. The indicator shows that the company respects the code of conduct and perceives inappropriate business policy. By detecting and measuring business incidents, we show that the company is committed to honest business, as the entire operation of the company can be jeopardized.

Indicator of ensuring green production shows an increase in resources in order to provide a greener production in the logistics field. It shows the budget intended for investment in sustainable improvements, as investments make it easier to achieve desired goals. We are citing the example of reducing energy consumption through the replacement of energy products, choosing more energy-efficient consumers, investing in alternative sources.

Indicator of cost reduction due to lean logistics shows improving the quality, productivity, efficiency and implementation of logistics processes with the active participation of all employees. Indicator shows whether the company uses these principles in a continuous improvement cycle and measures the cost reduction due to the implementation of lean logistics.

Indicator of cost reduction per SKU unit is a generally acknowledged indicator for the economically efficient implementation of logistics processes and measures the costs for a single logistic unit SKU (Stock Keeping Unit).

Indicator of improving the economic efficiency of transport shows the economic effects in improvements of internal or external transport per kilometer. Introduction of more economical and technologically-equipped means of transport, better efficiency in carrying out transport, route optimization, and loading methods bring economically measurable effects.

Indicator of reduction energy, wastewater and waste costs shows the economic justification of the economic green policy in logistic activities. Company that is introducing sustainable development, lean logistics and invests in the provision of green production expects to reduce costs for consumed energy, to reduce waste water and all other waste.

\section{$3 \quad$ RESULTS AND DISCUSSION}

We were researching logistic companies using questionnaire and interview methods. The research was carried out in the first half of 2017 and was related to data from 2015. We selected companies that identified their primary activity as a transport company, 3PL distribution center and commercial distribution center. With the questionnaire, companies calculated the 3PL GIF indicators. These are major Slovenian companies engaged in the logistics of the distribution of goods and cover land, air and sea transport. We have examined 6 companies which, due to business discretion, have been renamed $\mathrm{A}$, B, C, D, E, F. Companies A, B and D are transport companies, while companies $\mathrm{C}, \mathrm{E}$ and $\mathrm{F}$ are companies that provide logistical services as external or commercial distribution centers as Tab. 2 represents.

From the questionnaire we obtained data on how companies themselves assess the importance of sustainable areas. The importance of each pillar was assessed with the following values: $3=$ very important, $2=$ important $1=$ less important if no answer the value is 0 (see Tab. 2).

All companies studied are aware of the importance of all three sustainability pillars of environment, society and 
economy. Relevance of the environmental pillar is the smallest, but it does not deviate much from the other two pillars. We expect the company with its own high assessment of the importance of sustainability successfully carries out sustainable operation.

Table 2 Evaluation of the importance of ecology, economy and society fields, which was measured in individual companies

\begin{tabular}{|c|c|c|c|c|c|}
\hline Sign & Transport & $\begin{array}{c}\text { All logistics } \\
\text { activities }\end{array}$ & Environment & Society & Economy \\
\hline A & $\mathrm{X}$ & & 2 & 2 & 3 \\
\hline B & $\mathrm{X}$ & & 3 & 3 & 3 \\
\hline C & & $\mathrm{X}$ & 3 & 3 & 3 \\
\hline D & $\mathrm{X}$ & & 2 & 3 & 3 \\
\hline E & & $\mathrm{X}$ & 2 & 3 & 3 \\
\hline F & & $\mathrm{X}$ & 3 & 3 & 3 \\
\hline
\end{tabular}

The results show that all companies are aware that it is necessary to measure and monitor the operation in all three fields of sustainable operation, so the average value in ecology is 2.5 , in society slightly higher at 2.8 and in economy is maximum at 3 .

\subsection{Environmental Results}

Tab. 3 represents environmental indicator values of all companies (named A to F). The table includes both segments: implementation of environmental policy and impact on the environment. Where no values are shown, indicators are not measured. We can conclude that most companies strive to reduce emissions, pollution and water consumption, while two companies do not measure and report on environmental performance. It is even worse in solid waste reduction.

Table 3 Values of indicators in the implementation of environmental policy and impact on the environment

\begin{tabular}{|c|c|c|c|c|c|c|}
\hline Environmental indicator / Company & $\mathrm{A}$ & $\mathrm{B}$ & $\mathrm{C}$ & $\mathrm{D}$ & $\mathrm{E}$ & $\mathrm{F}$ \\
\hline Success of environmental standard use & 12.50 & 8.33 & 11.25 & 12.50 & 12.50 & 12.50 \\
\hline Reducing energy consumption & 12.50 & 8.33 & 9.38 & 12.50 & 6.25 & 12.50 \\
\hline Reduction of the scope of recycling & 8.33 & NA & 11.25 & 12.50 & 12.5 & 8.33 \\
\hline Reduction of environmental incidents & N/A & NA & 12.38 & NA & NA & NA \\
\hline Measurement and reporting on environmental performance & 12.50 & NA & 11.25 & NA & 12.50 & 12.50 \\
\hline Reduction of emissions into the air & 12.50 & 8.33 & 9.38 & 12.50 & 6.25 & 12.50 \\
\hline Reduction of water pollution and consumption & 0,00 & NA & 9.38 & 12.50 & 12.5 & 12.50 \\
\hline Reduction of solid waste & 2.50 & NA & 9.38 & NA & 12.5 & 2.50 \\
\hline
\end{tabular}

Companies $\mathrm{A}, \mathrm{B}$ and $\mathrm{D}$ are transport companies. Company A does not monitor the pollution and consumption of water and is modest in reducing solid waste. Company B pays attention only to reducing air emissions, while company $\mathrm{D}$ achieves better results especially in reducing emissions and water consumption. Companies that perform external logistics services are companies $\mathrm{C}, \mathrm{E}$ and $\mathrm{F}$, and they have indicators with higher value than transport companies. Company $\mathrm{C}$ is a prominent external contractor and has very high performance in all environmental indicators. Companies $\mathrm{E}$ and $\mathrm{F}$ also have high results in environmental indicators, where $\mathrm{E}$ lags behind in reducing emissions and $\mathrm{F}$ in reducing solid waste.

\subsection{Society Results}

Results of the indicators value in the social field are shown in Tab. 4. Results show that most companies do not measure all indicators. Where indicators are measured, they are sufficiently successful and indicate the commitment of companies to improving the social field.
These are social security indicators, occupational safety indicators and education and working conditions indicators.

It is surprising that some companies do not pay attention to improving working conditions and the environment in which employees work. Company A does not improve social security and working conditions, and company B does not work to improve safety and working conditions. Companies $\mathrm{C}$ and $\mathrm{D}$ show progress in all areas of social policy. Of all three indicators, company $\mathrm{E}$ improves only employees' safety, while company $\mathrm{F}$ as most, does not improve working conditions. On the other hand company A does not increase preventive measures in improving the social situation, Company B also does not pay attention to the increase of preventive measures. Companies D and $\mathrm{E}$ do not improve the education and quality of employees' environment. With company $\mathrm{F}$, the measurement results are very high, but they do not measure the improvement of the quality of the employees' environment.

Table 4 Values of indicators on the implementation of social policy and social situation

\begin{tabular}{|c|c|c|c|c|c|c|}
\hline Social indicator / Company & $\mathrm{A}$ & $\mathrm{B}$ & $\mathrm{C}$ & $\mathrm{D}$ & $\mathrm{E}$ & $\mathrm{F}$ \\
\hline Improvement of employee social security & NA & 11.43 & 7.14 & 14.29 & NA & 14.29 \\
\hline Improvement of logistical production safety & 7.14 & NA & 11.43 & 14.29 & 7.14 & 14.29 \\
\hline Improvement of working conditions & NA & NA & 10.71 & 14.29 & NA & NA \\
\hline Improvement of work environment quality & 8.57 & 14.29 & 11.43 & NA & NA & NA \\
\hline Increase of preventive measures & NA & NA & 10.00 & 11.69 & 7.14 & 14.29 \\
\hline Reduction of accidents & 14.29 & NA & 14.29 & 11.43 & 7.14 & 14.29 \\
\hline Increase of education & 4.76 & 10.71 & 10.71 & NA & NA & 14.29 \\
\hline
\end{tabular}

\subsection{Economy Results}

Results of the economy indicators $d$ are shown in Tab. 5. The data show that company A, especially in the field of logistics, does not acquire economic performance data, but the data is covered in the entire business of the company. It is similar in company $\mathrm{F}$, where the increase in market share does not seem important to them. No company measures the incidents that arise due to the controversial, incorrect behavior that does not correspond to the code of 
conduct, nor do they have measurements performed and a foreseeable way to reduce them. Results show that half of the companies do not pay attention to implementing their operations according to the principles of lean logistics. It is also surprising that two-thirds of companies do not measure the costs per individual logistics unit, which is otherwise a very important indicator for the performance of operations in transport and storage. However, most companies are interested in the economic efficiency of transport as this represents a significant cost in logistics. Two-thirds of companies also do not record efficiency in saving of energy, water and in reduction of waste materials.

Table 5 Values of the performance indicators of the company's economic policy and green economic policy

\begin{tabular}{|c|c|c|c|c|c|c|}
\hline Environmental indicator / Company & A & $\mathrm{B}$ & $\mathrm{C}$ & $\mathrm{D}$ & $\mathrm{E}$ & $\mathrm{F}$ \\
\hline Market share increase & NA & 9.38 & 11.43 & 12.50 & 0,00 & NA \\
\hline Income and profitability increase & NA & 8.33 & 14.29 & 12.50 & 14.29 & 11.46 \\
\hline Operation by code of conduct & NA & NA & NA & NA & NA & NA \\
\hline Economic effort to ensure green production & NA & 9.38 & 10.71 & 8.33 & NA & 12.50 \\
\hline Cost reduction due to lean logistics & 6.25 & NA & 14.29 & NA & NA & 12.50 \\
\hline Cost reduction per Stock Keeping Unit (SKU) & 6.25 & NA & NA & NA & NA & 12.50 \\
\hline Improvement of transportation economic efficiency & 1.25 & 6.25 & 10.00 & 12.50 & NA & 12.50 \\
\hline Reduction of energy, waste water, waste costs & NA & NA & 7.14 & NA & NA & 12.50 \\
\hline
\end{tabular}

\subsection{PL GIF Index Economy Results}

The Index combines individual indicators for each field of ecology, society and economy separately into a combined result. For company $\mathrm{D}$, the sum of the environmental policy indicators is $12.5+12.5+12.5+0=$ 37.5 , and for the field of environmental impact measurement $0+12.5+12.5+0=25.0$. Therefore, the total value of the index for company $\mathrm{D}$ in the field of ecology is $37.7+25.0=62.5$.

The 3PL GIF index comparison graph (Fig. 1) shows the performance in the ecological, social and economic field and the comparison between companies. Among the research companies, the 3PL GIF index clearly shows the differences and draws attention to areas where something needs to be changed.

Sustainability declarative importance versus 3PL GIF index

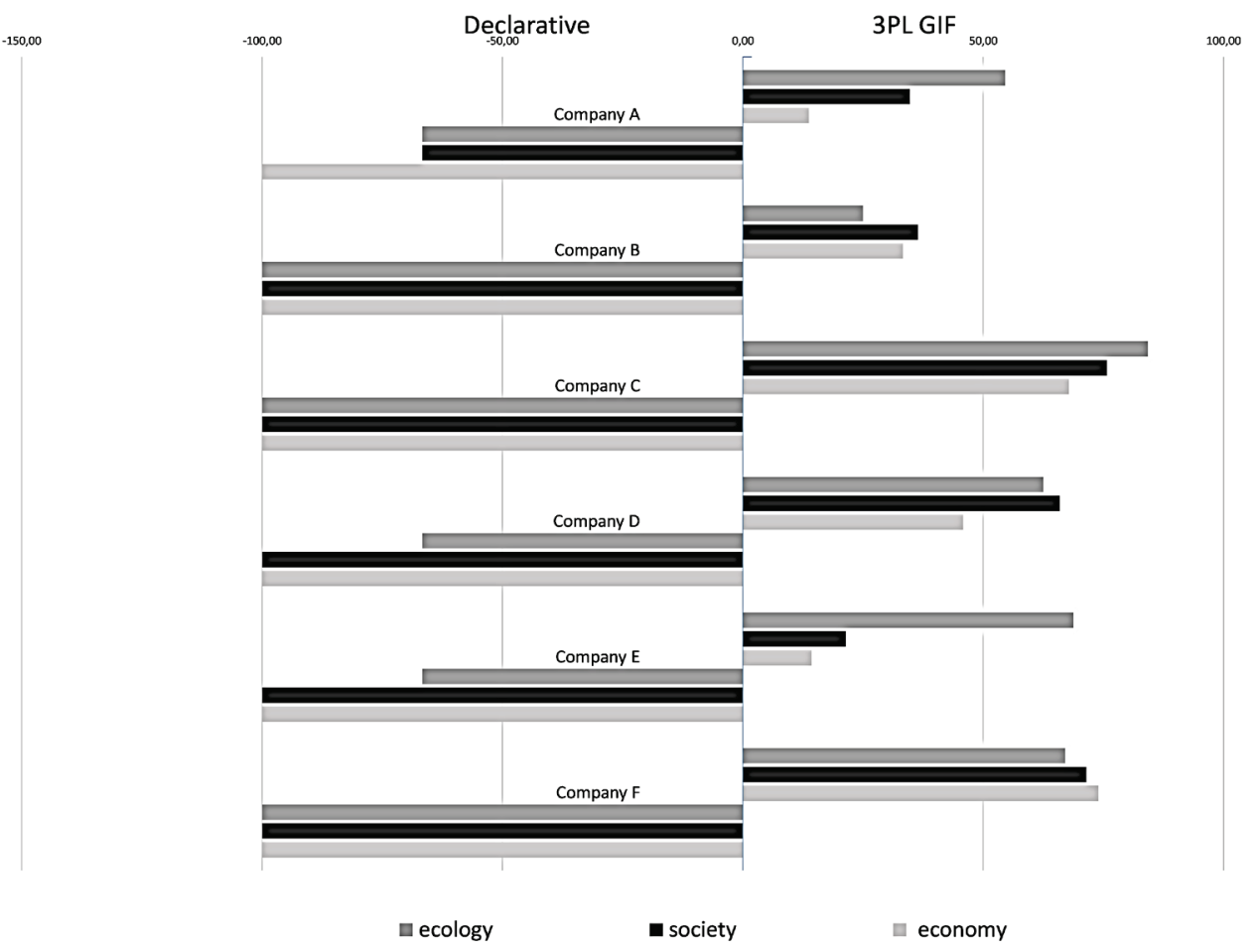

Figure 1 Comparison of assessment of the importance of the fields with 3PL GIF

Companies themselves assessed the importance of sustainable fields (Tab. 2), where most assessments are the maximum, which means that they are extremely committed to sustainable operation. When we compare this with the results shown by the 3PL GIF index, some companies see significant discrepancies that warn that these companies should make additional efforts where a pronounced deficit is detected.
We made a comparison with the assessment of the importance of the fields of ecology, economy and society, which was measured in individual companies with the results of the 3PL GIF index. In order to be able to compare the score from 0 to 3 , the assessments were normalized to values from 0 to 100 . Thus, assessment 1 in the importance of the field represents a value of 33.3 out of 100 possible. In the Fig. 1, on the left side of the graph there are companies' assessments of the importance of individual 
field and on the right side in the horizontal direction the 3PL GIF index. Companies are declaratively clear about the importance of environmental performance as most assessments are the highest. However, in the studied companies, there is a significant difference between declarative and real implementation, which is illustrated by the 3PL GIF index, which shows measured performance in sustainable development. Thus, we see a big divergence in companies $\mathrm{A}$ and $\mathrm{B}$, and $\mathrm{F}$, which shows a big difference between their own assessment and the real result

\section{CONCLUSIONS}

The purpose of the 3PL GIF is to enable each logistic company to gain insight into the sustainable progress of business policy in the field of ecology, society and the economy, and the insight on how it progresses in its operation.

Independence from company size is the advantage of this model, as it is useful for demonstrating the performance of a wide variety of logistics companies from small local family businesses to global giants, with the same goal of being more successful in its operation.

Transparent and easy to obtain data for 3PL GIF is ensured, since the company is expected to use international quality standards to set up a sustainable policy and continuously measure and improve its performance.

In addition to measuring the situation itself, the entire structure of the model also serves to control and achieve the set goals for all logistical activities according to the principles of cyclical improvements, lean logistics and continuous progress in the sustainable field.

3PL GIF model is a tool that enables companies and the entire supply chain information on the performance of logistics services implementation and the progression of the most important sustainability elements, with simple comparisons between different companies and an efficient system for structured and easy reporting.

The model takes into account the growing trend of transparency and visibility in the operation of supply chains, so that stakeholders who are interested in the data from the 3PL GIF can be divided into four groups:

Managers of individual logistics companies who want to achieve more successful operations.

Whole supply chain managers who can choose better performers also in the sustainable field.

Customers of logistics services with external contractors.

Final consumers of goods so they can find out with which companies a particular product traveled through the supply chain.

In today's competitive environment, the ability to show effort in the sustainable operation with 3PL GIF can also be a certain advantage for logistics companies and the entire supply chain.

The model demonstrated instant usefulness in the survey for the assessment of sustainable implementation since data mostly existed and all of the studied companies use the quality standards. Due to the method of selecting indicators, many assessments can be verified because they are linked to international quality performance standards. Unsuccessful companies are unlikely to want to provide information, but even such information is useful since it indicates that the contractor does not care about sustainable development.

Company's big commitment to a more sustainable operation surprises, which is reflected in the assessment of the importance of sustainable fields, but some companies show more on the declarative level than in the implementation itself.

3PL GIF enables companies to improve their performance and constantly measure and compare their performance with the competition, and also provides information of the general public from producers, clients, contractors and consumers, in which way and how successfully in the sense of sustainably logistic services have been carried out.

We assume that the model will contribute to transparent notification on logistics performance, easier selection of logistics providers and more sustainable implementation of logistics services.

Trend of development and the basis of business models requires taking into account sustainable indicators that place suppliers of logistics services at a certain level of quality, thereby affecting their desirability among all stakeholders in supply chains. 3PL GIF model is an appropriate and long-term interesting solution for measuring the environmental performance in storage, transport, and the entire distribution of goods and services.

\section{REFERENCES}

[1] Executive Order 13423 (Jan. 26, 2007). Strengthening Federal Environmental, Energy and Transportation Management, 72 Federal Register 3919. Retreived fromhttp://www.ofee.gov/eo/eo_13423.pdf

[2] Gualandris, J., Klassen, R. D., Vachon, S., \& Kalchschmidt, M. (2015). Sustainable evaluation and verification in supply chains: Aligning and leveraging accountability to stakeholders. Journal of Operations Management, 38, 1-13. https://doi.org/10.1016/j.jom.2015.06.002

[3] Oršič, J., Jereb, B., \& Rosi, B. (2016). Tracking sustainable success in supply chains. 8. conference Information Technology in Public Administration IJU 2016.

[4] Jereb, B., Cvahte, T., \& Rosi, B. (2016). Sustainable Logistics and Strategic Transportation Planning. In Advances in logistics, operations, and management science book series (Print), ISSN 2327-350X, 236-247. Hershey: IGI Global.

[5] Meixell, M. J. \& Luoma, P. (2015). Stakeholder pressure in sustainable supply chain management: A systematic review. International Journal of Physical Distribution \& Logistics Management, 45(1/2), 69-89. https://doi.org/10.1108//JPDLM-05-2013-0155

[6] Langley, C. J. (2010). 15 th annual study 2010 Third Party Logistics. Capgemini.

[7] Large, R. O., Kramer, N., \& Hartmann, R. H. (2013). Procurement of logistics services and sustainable development in Europe: Fields of activity and empirical results. Journal of Purchasing and Supply Management, 19(3), 122-133. https://doi.org/10.1016/j.pursup.2013.05.002

[8] Evangelista, P., Colicchia, C., \& Creazza, A. (2017). Is environmental sustainability a strategic priority for logistics service providers? Journal of Environmental Management, 198, Part 1, 353-362. https://doi.org/10.1016/j.jenvman.2017.04.096

[9] Rajsman, M. \& Pros, N. (2014). Integrated management system of a transport company. Tehnički vjesnik, 21(5), 1165-1175. Retrieved from https://hrcak.srce.hr/129133. 
[10] Gunasekaran, A., Pattel, C., \& McGaughey, R. E. (2004). A framework for supply chain performance measurement International Journal of Production Economics, 87(3), 333347. https://doi.org/10.1016/.ijpe.2003.08.003

[11] Vachon, S. \& Klassen, R. (2006). Extending green practices across the supply chain. International Journal of Operations, 26(7), 795-821. https://doi.org/10.1108/01443570610672248

[12] Ahi, P. \& Searcy, C. (2013). A comparative literature analysis of definitions for green and sustainable supply chainmanagement. Journal of Cleaner Production, 52, 329. 341. https://doi.org/10.1016/j.jclepro.2013.02.018

[13] Carter, C. \& Rogers, D. (2008). A framework of sustainable supply chain management: moving toward new theory. International Journal of Physical Distribution \& Logistics Management, 38(5), 360-387. https://doi.org/10.1108/09600030810882816

[14] Srivastava, S. (2007). Green supply-chain management: A state-of-the-art literature review. International Journal of Management Reviews, 9(1), 53-80. https://doi.org/10.1111/j.1468-2370.2007.00202.x

[15] Hsu, A., Johnson, L. A., \& Lloyd, A. (2013). Measuring Progress: A Practical Guide From the Developers of the Environmental Performance Index (EPI). New Haven:Yale Center for Environmental Law \& Policy

[16] Böhringer, C. \&. Jochem, P. (2007). Measuring the Immeasurable:A Survey of Sustainability Indices. Retrieved from http://ftp.zew.de/pub/zew-docs/dp/dp06073.pdf. https://doi.org/10.1016/j.ecolecon.2007.03.008

[17] Evangelista, P., Sweeney, E., Ferruzzi, G., \& Carrasco, J. (2014). Green supply chains initiatives in transport and logistics service industry: an exploratory case study analysis. Research in Transportation Business \& Management, 12(10), 63-72. https://doi.org/10.1016/j.rtbm.2014.10.002

[18] Marchet, G., Melacini, M., \& Perotti, S. (2014). Environmental sustainability in logistics and freight transportation. Journal of Manufacturing Technology Management, 25(6), 775-811. https://doi.org/10.1108/JMTM-06-2012-0065

[19] OECD. (1991). The state of the environment. Paris: OECD.

[20] Serageldin, I. (1996). Sustainability and the wealth of nations: first steps in an ongoing journey. Environmentally sustainable development studies and monographs series, no. $5 *$ ESSD Environmentally \& Socially Sustainable Development Work in Progress. Washington, D. C. The World Bank. https://doi.org/10.1596/0-8213-3549-9

[21] Elkington, J. (1999). Triple bottom-line reporting: Looking for balance. Australian CPA, 69(2),18-21. https://doi.org/10.1108/eb025539

[22] ISO 14031:2013(en) Environmental management Environmental performance evaluation - Guidelines. Retrievedfrom https://www.iso.org/obp/ui/\#iso:std:iso: 14031:ed-2:v1:en.

[23] Zhu, Q., Sarkis, J., \& Lai, K. H. (2008). Confirmation of a measurement model for green supply chain management practices implementation. International Journal of Production Economics, 111(2), 261-273. https://doi.org/10.1016/j.ijpe.2006.11.029

[24] Walmart. (2009, March 17-18). Wal-Mart's Sustainability Journey. Retrieved from https://www.sustainabilityconsortium.org/wp-content/ uploads/wal-marts-sustainability-journey.pdf

[25] Nehm, A. \& Schwemmer, M. (2011). Nachhaltigkeitsindex für Logistikdienstleister. Frauenhofer. Retrived from https://www.scs.fraunhofer.de/de/studien/nachhaltigkeit/Na chhaltigkeitsindex fuer_Logistikdienstleister.html

[26] Welsch, H. (2005). Constructing meaningful sustainability indices. Applied Research in Environmental Economics $7-$ 22. Springer. https://doi.org/10.1007/3-7908-1645-0_2
[27] ISO $14001 \quad$ Requirements. Retreived from http://www.iso14001.com.au/iso-14001-requirements.html.

[28] Hervani, A. H. (2005). Performance measurement for green supply chain management. Benchmarking: An International Journal, 12(4), 330-353. https://doi.org/10.1108/14635770510609015

[29] EEA European Environment Agency. (2003). Environmental Indicators: Typology and Use in Reporting. Copenhagen: EEA.

[30] Warhurst, A. (2002). Sustainability indicators and sustainability performance Management Report to the Project: Mining, Minerals and Sustainable Development.Warwick, England. Obtained from International Institute for Environment and Development (IIED).

[31] Krajnc, D. \& Glavič, P. (2005). A model for integrated assessment of sustainable development. Resources, Conservation and Recycling, 43, 189-208. https://doi.org/10.1016/S0921-3449(04)00120-X

[32] Mayer, A. (2008). Strengths and weaknesses of common sustainability indices for multidimensional systems. Environment International, 34, 277-291. https://doi.org/10.1016/j.envint.2007.09.004

[33] Zegras, C. (2006). Sustainable Transport Indicators and Assesment Technologies. Biannual Conference and Exhibit of the Clean Air Initiative for Latin American Cities. São Paulo, Brazil.

[34] Škerlič, S., Muha, R., \& Logožar, K. (2016). A decisionmaking model for controlling logistics costs. Tehnički vjesnik, 23(1), 145-156. https://doi.org/10.17559/TV-20141015121023

[35] Koepfel, I. (2001). Dow Jones Sustainability Group Index: A Global Benchmark for Corporate Sustainability. Corporate Environmental Strategy, 8(1), 6-15. https://doi.org/10.1016/S1066-7938(00)00089-0

\section{Contact information:}

Jerko ORŠIČ, Prof. BSC

Menteklogonet d.0.o.

Trzaska 282, 1000 Ljubljana, Slovenia

jerko.orsic@mentek.si

Bojan ROSI, PhD, Prof.

University of Maribor, Faculty of Logistics, Mariborska cesta 7, 3000 Celje, Slovenia bojan.rosi@um.si

Borut JEREB, PhD, Assoc. Prof.

University of Maribor, Faculty of Logistics, Mariborska cesta 7, 3000 Celje, Slovenia borut.jereb@um.si 